\title{
Molecular genetics of familial breast-ovarian
} cancer

\author{
E J van Rensburg, B A J Ponder
}

Breast cancer is a common malignancy in women and although the great majority are due to acquired mutations, there is now unequivocal evidence that approximately $5 \%$ of breast cancer cases may be due to an inherited predisposition. Family studies have identified clustering of breast and/or ovarian cancer consistent with autosomal dominant inheritance. ${ }^{1-3}$ Many epidemiological studies show that the risk of breast or ovarian cancer in the relatives of patients with breast or ovarian cancer is higher than in the general population.

\section{Evidence for genetic predisposition}

Numerous case-control studies of familial risks of breast cancer have been carried out, but by far the largest published one is that based on the Cancer and Steroid Hormone (CASH) study (conducted by the Centers for Disease Control). ${ }^{4}$ Key findings of this study are that the risk of breast cancer in relatives of patients with breast cancer increases with decreasing age of the index case, and is greater for women with several affected relatives than for women with one affected relative. Using the family history data of 4730 breast cancer probands from the CASH study, Claus et $a l^{5}$ performed a segregation analysis of a hypothesised breast cancer susceptibility locus and found that familial clustering of breast cancer could best be explained by the inheritance of an autosomal dominant gene with a population frequency of $0 \cdot 0033$. This dominant gene confers a cumulative risk of breast cancer of $38 \%$ by 50 years of age and $67 \%$ by 70 years of age in gene carriers, compared with $1.5 \%$ by 50 years of age and $5 \%$ by 70 years of age in non-carriers. In this model more than one third of the breast cancer, cases diagnosed before 30 years of age are estimated to be due to the susceptibility gene. This contribution falls to about $1 \%$ of cases diagnosed over the age of 80 years. ${ }^{5}$ Similar models have been obtained by other authors. ${ }^{67}$ Ovarian cancer, which has an incidence of about one fifth of that of breast cancer, also has a familial component ${ }^{2}$ and is sometimes associated with familial breast cancer. $^{3}$ The risk of ovarian cancer is moderately increased in relatives of women with breast cancer and vice versa. ${ }^{38}$ This observation suggests the existence of a gene predisposing to both breast and ovarian cancer.
Although the epidemiological data are consistent with a single major gene effect in both breast and ovarian cancer, it is clear that several predisposing genes are involved (that is, genetic heterogeneity) (discussed later). At least two other familial syndromes have been identified for which an increased risk of developing breast cancer is well established: the $\mathrm{Li}-$ Fraumeni syndrome, a rare autosomal dominant cancer syndrome involving childhood sarcomas, early onset breast cancer, brain tumours and a number of other cancers, ${ }^{9}$ and ataxia telangiectasia, a rare autosomal recessive disease in which homozygotes develop a progressive cerebellar ataxia, hypersensitivity to ionising radiation and a striking predisposition to cancer. ${ }^{10}$ It is now well established that ataxia telangiectasia heterozygotes have an excess risk of cancer in general and breast cancer in particular. ${ }^{10}$

\section{Searching for the predisposing gene(s) GENETIC LINKAGE}

Provided that multiple case families are available and that the inherited predisposition in any one family is due largely to the effects of a single gene, it is possible to search for the predisposing gene using genetic linkage analysis. ${ }^{11}$ Linkage mapping is dependent on the availability of useful DNA linkage markers (sequences) positioned beforehand on a reference map of a specific chromosome.

Linkage analysis is based on the ability to find DNA markers of known chromosomal location that are consistently co-inherited with the disease state (taken to represent the presence of the disease gene) in affected families. If the DNA marker and disease gene are located close together on the same chromosome they will tend to be inherited together and are said to be "linked" (fig 1A). However, parental chromosomes become closely apposed at meiosis and exchange (crossing-over) of chromosomal material between the chromosomal homologues can occur, so that the marker and disease gene will part in some offspring, known as "recombinant" individuals (fig 1B). Thus, the closer together a marker and disease gene are on the same chromosome the less will be the chance of crossing-over.

The probability that the observed inheritance pattern of the marker and disease could have occurred because they were physically linked 

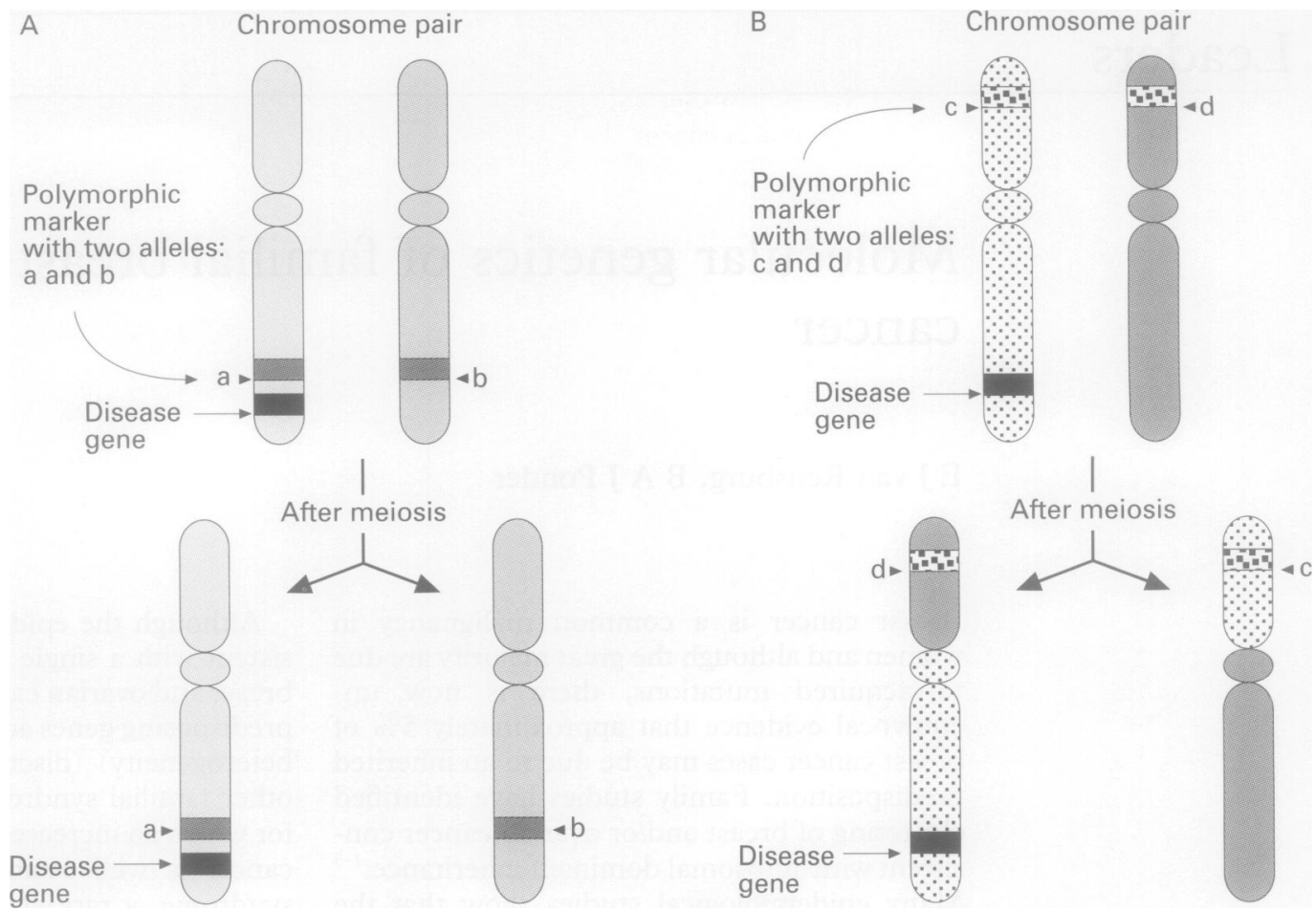

Figure 1 Illustration of linkage $(A)$ and recombination $(B)$ of a marker locus and disease gene. In panel $A$ the disease gene and marker locus are nearby on the same chromosome and co-segregate (are inherited together), thus showing linkage. In panel $B$ the disease gene and marker locus are far apart on the same chromosome with no linkage and thus segregate independently of each other.

(at a specified distance) on the same chromosome is calculated and expressed as a ratio relative to the probability that the same result would have been observed if the marker and disease gene were unlinked (that is, inheritance occurred by chance alone). This ratio expresses the odds for (or against) linkage and because the logarithm of the ratio is used it is known as the "LOD score" (logarithm of the odds). A LOD score of $>3$ is considered proof of positive linkage (odds of 1000:1 in favour of linkage). For a more detailed discussion of linkage analysis the reader is referred to Ott. ${ }^{11}$

Linkage analysis has been revolutionised with the advent of microsatellite markers which are readily typed using the polymerase chain reaction (PCR). ${ }^{12}$ These markers are sequences containing di-, tri-, and tetra-nucleotide repeats which are frequently highly polymorphic and often possess dozens of alleles. ${ }^{13}$ The variable repeat region can be amplified by PCR using unique flanking primers followed by analysis of the length of the PCR products on denaturing polyacrylamide gels. Members of a family with inherited breast cancer can thus be typed for polymorphic markers, and haplotypes (that is, groupings of alleles carried on homologous chromosomes (fig 2)) deduced, which are then used to determine whether the disease is segregating with a specific marker. This is done by calculating LOD scores for each of the markers relative to the inheritance of breast cancer.

Using a highly polymorphic marker, pCMM86, defining the locus D17S74 on chromosome $17 \mathrm{q}$, Hall et $a l^{14}$ found significant evidence of linkage between breast cancer and the marker in 23 multiple case breast cancer families. This was the first convincing local- isation of a breast cancer gene by genetic linkage. However, there was significant evidence of heterogeneity with linkage confined to those families with a mean age of onset of less than 46 years (LOD score 5.98). Subsequent reanalysis allowing for sporadic cases (as breast cancer is so common, these families may contain a proportion of sporadic cases) showed that evidence against linkage in the later-onset families was no longer significant. ${ }^{15}$ In these families the occurrence of breast cancers unrelated to the inheritance of the predisposing gene had given the spurious impression that the families were unlinked. Confirmation of linkage to $17 \mathrm{q}$ in five families with multiple cases of both breast and ovarian cancer was provided by Narod et al. ${ }^{16}$ This study also found evidence of genetic heterogeneity with linkage restricted to three of the five families tested. This breast-ovarian cancer predisposing locus is now known as BRCA1. ${ }^{17}$

In order to expand the linkage evidence on $17 \mathrm{q}$ in breast and breast-ovarian cancer families an international linkage consortium analysed 214 families using a panel of six polymorphic markers in the region of the BRCA1 gene. ${ }^{18}$ Based on their genotyping results, it was estimated that $45 \%$ of families with breast cancer only, and virtually $100 \%$ of families which contained breast cancer and at least one ovarian cancer case, were linked to 17q. The distinction between $17 \mathrm{q}$ linked and unlinked breast cancer families could not entirely be explained by age of disease onset, although it did appear that a greater proportion of families with early-onset disease were linked to chromosome 17q. The unlinked families are either predisposed at another locus (there is genetic heterogeneity) or, given the high rate 


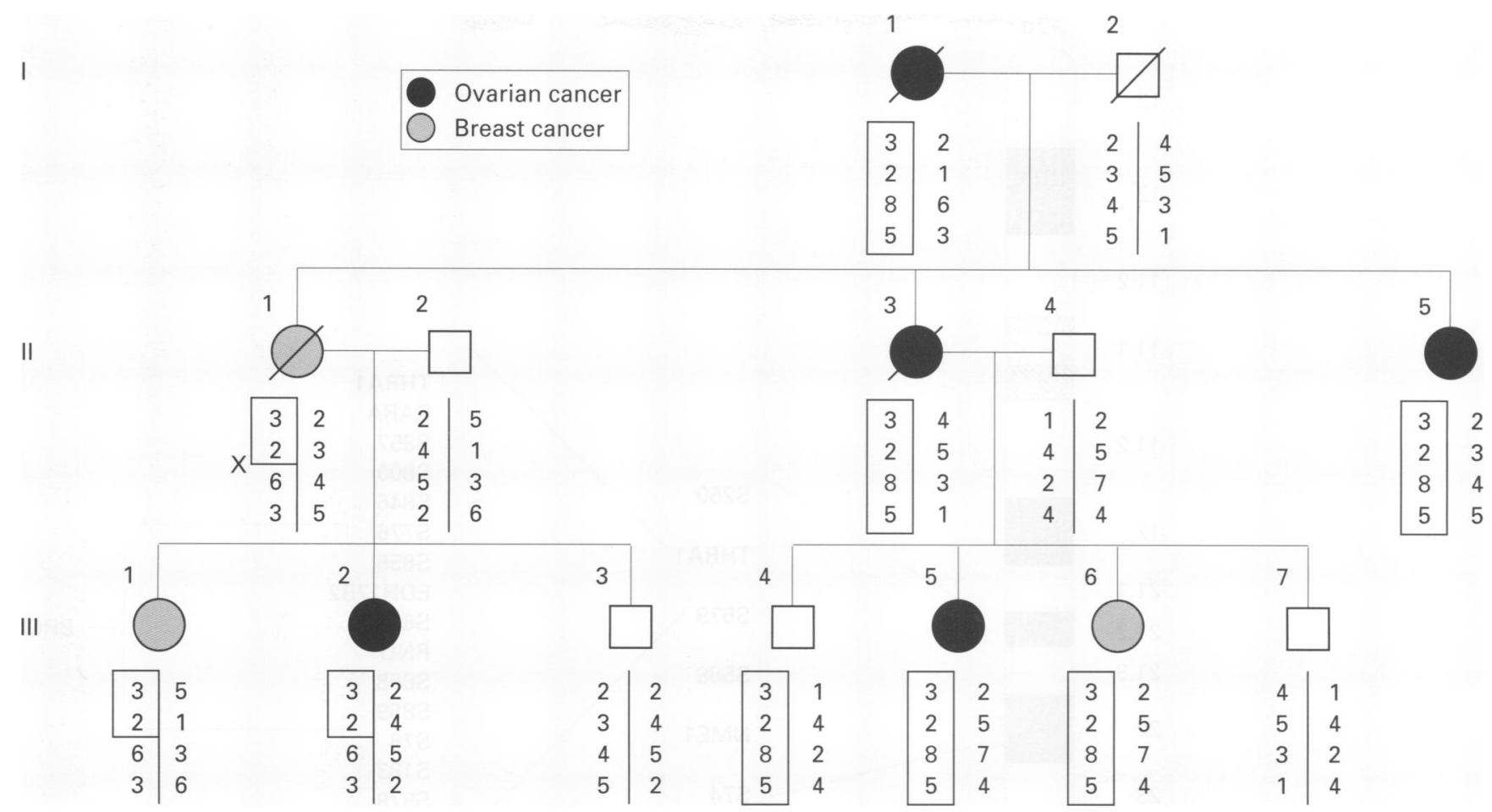

Figure 2 Pedigree of a family with inherited breast and ovarian cancer illustrating a recombination event. The family members have been typed for each of the five polymorphic marker loci D17S858, D17S859, D17S78, D17S183 and D17S579 on chromosome 17q. Haplotypes (groups of alleles carried on each of the homologous chromosomes) have been deduced and inheritance of the cancer appears to be linked to the region defined by loci D17S858 and D17S859 (haplotype 3, 2). Recombination, marked by "X" (in individual II-1 and passed on to individuals III-1 and III-2), eliminates loci distal to D17S859. This therefore places the gene proximal to D17S859.

of sporadic breast cancer, may represent coincidental occurrence of breast cancer in relatives. However, some of these unlinked families are so large that they demonstrate genetic susceptibility. Furthermore, no breast cancer families containing male breast cancer cases have been linked to BRCA1. In a recent study of 22 families with at least one case of male breast cancer, Stratton et $\mathrm{l}^{19}$ found strong evidence against linkage to BRCA1, indicating that there is a gene other than BRCA1 which predisposes to early-onset breast cancer in women and which confers a higher risk of male breast cancer.

By examining recombinants in extended pedigrees which show clear evidence of linkage to a given locus, one can narrow down the region which is genetically linked to a disease gene (fig 2). In this way the Consortium study localised BRCAl to an interval flanked by markers mfd15 (D17S250) and 42D6 (D17S588). More recent typing of other markers in informative recombinants in linked families has helped to delineate the critical region containing BRCA1 further (fig 3). The proximal boundary has been demonstrated to be below D17S776 ${ }^{20}$ and D17S702. ${ }^{21}$ With regard to the distal flanking markers, it has been shown that BRCA1 is proximal to $\mathrm{D} 17 \mathrm{~S} 183^{22}$ and D17S78. ${ }^{23}$

With the narrowing of the minimal region containing BRCA1, most of the already known potential candidate genes for BRCA1 which map to this chromosomal interval have now been excluded by linkage. The last of these, the gene for $17 \beta$-oestradiol dehydrogenase (EDH17B2), was excluded by direct sequencing of the entire gene, including all the introns and 867 bases upstream from the first exon, in four unrelated affected women from families with linked breast-ovarian cancer. ${ }^{23}$ No sequence abnormalities were detected, other than previously described polymorphisms. Kelsell et al ${ }^{4}$ obtained similar results after sequencing three affected members of a large breast-ovarian cancer family. Mutations in the EDH17B2 gene, therefore, do not appear to be responsible for the hereditary breast-ovarian cancer syndrome. It now seems most likely that BRCA1 is a new gene which has yet to be identified.

\section{ALLELE LOSS}

Two categories of genes are thought to be involved in the pathogenesis of cancer-that is, proto-oncogenes and tumour suppressor genes. ${ }^{25}$ Genetic damage (mutation) of a protooncogene leads to altered activity or increased expression of the corresponding protein product which can contribute to abnormal growth of cells. This gain of function mutation is seen as dominant acting in the sense that the mutated allele is dominant (that is, overriding) over the normal allele. By contrast, tumour suppressor genes, which are believed to be involved in the normal suppression of cellular proliferation, are commonly inactivated in tumours (loss of function mutations). ${ }^{26}$ Tumour suppressor gene mutations are recessive to the normal allele thus necessitating the inactivation of the second wild-type allele for tumour formation $^{26}$ - the two hit mechanism proposed by Knudson ${ }^{27}$ and first confirmed in retinoblastoma. 


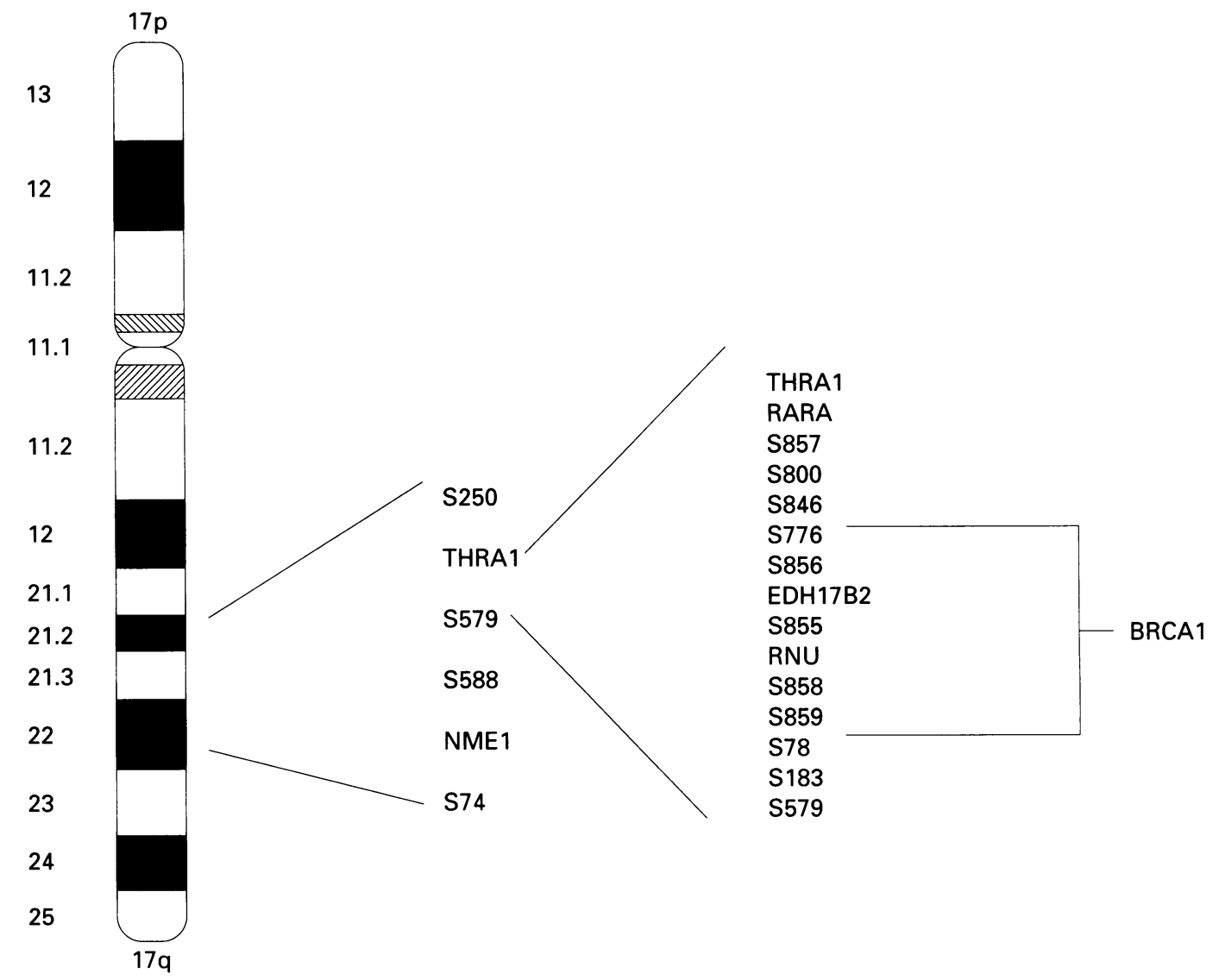

Figure 3 Schematic representation of polymorphic markers on chromosome $17 q$ linked to familial breast and ovarian cancer. Various studies of recombinant individuals have narrowed down the region which contains BRCA1 to between D17S776 and D17S78.

The essential features of Knudson's two hit model are that in the familial form of cancer the affected person inherits a mutated loss of function allele from one parent (which means that there is only one copy of the normal gene present in all cells), and then a somatic mutation in the target tissue inactivates the normal allele inherited from the other parent. In nonhereditary cancers both inactivating mutations have to occur within the same somatic cell. Malignancy is therefore likely to be a more frequent occurrence in those individuals who carry a heterozygous mutation in their germline (that is, predisposition to cancer). Inheritance of the predisposition follows a dominant pattern even though it is transmitted by recessive mutations.

In the inherited forms of cancer (such as retinoblastoma), the second (somatic) mutation that affects the normal (wild-type) allele and uncovers the germline recessive mutation is usually chromosome loss or deletion. This results in the absence of genetic material inherited from one of the parents and can be detected by the loss of heterozygosity $(\mathrm{LOH})$ for DNA markers at a specific chromosomal locus in the tumour (fig 4). ${ }^{28}$ Consistent LOH in tumours can be used as an indication of the

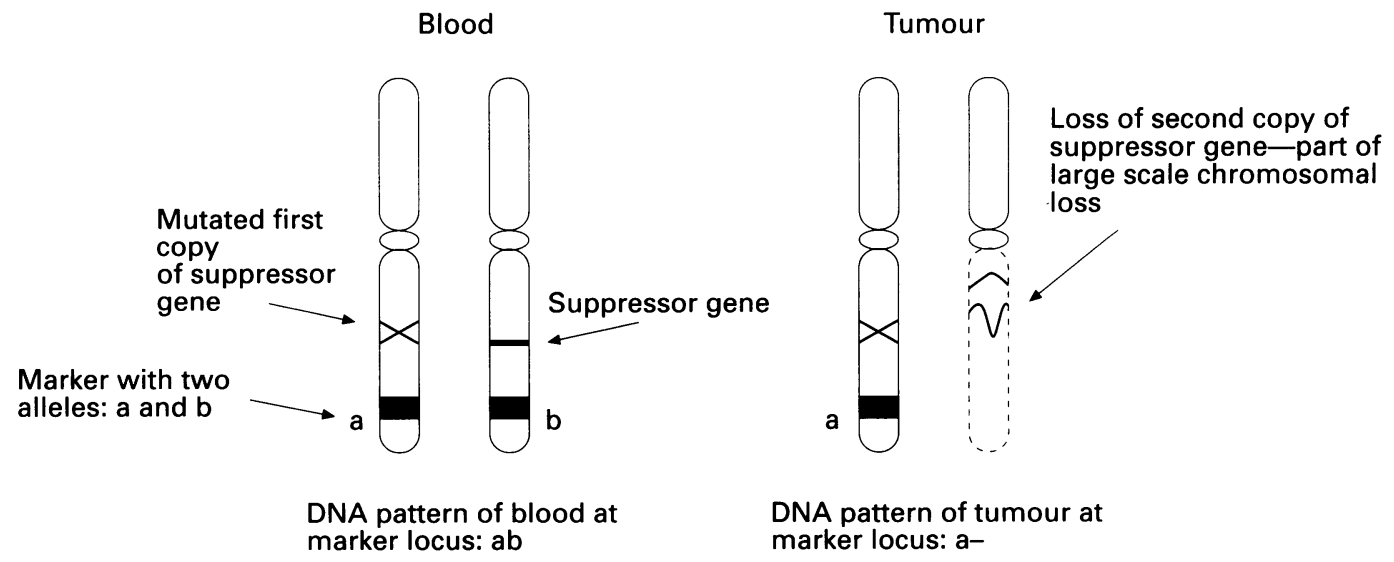

Figure 4 Use of loss of heterozygosity in searching for suppressor genes. A pair of chromosomes which carry a locus for a suppressor gene is shown. Loss of the second copy of the suppressor gene is accompanied by large scale loss of chromosomal material from that region, which is detected as loss of one allele (b) at a marker locus on the chromosome. (Adapted from Ponder ${ }^{29}$.) 
presence of a tumour suppressor gene and help to identify the region of the chromosome which may contain the gene. This approach was successfully applied-for example, in identifying the cyclin dependent kinase 4 inhibitor gene (also known as p16 or as the multiple tumour suppressor gene, MTS1). Because of the high frequency of deletion at chromosome $9 p$, band 21 in malignant melanomas, gliomas, lung cancers, leukaemia, and many other cancer cell lines it was suggested that this region may contain a tumour suppressor gene which is involved in the genesis of several tumour types. Two research groups $^{3031}$ independently investigated this region and managed to narrow down the area by determining the most frequently deleted region in $9 \mathrm{p} 21$. Subsequent sequence analysis of the region led to the discovery that deletions in the MTS1 gene were responsible for these cancers.

This approach has been less useful in defining the location of BRCA1. With regard to familial breast-ovarian cancers, Smith et al $^{32}$ in a study of four breast-ovarian cancer families with disease linked to chromosome $17 \mathrm{q}$ found allele losses in the BRCA1 region in nine of the 13 tumours studied. Where allele losses were detected they invariably involved the wild-type (non-mutant) chromosome. This suggests that BRCA1 is a tumour suppressor gene and that inactivation or loss of both copies of this gene is required for tumour development. An alternative possibility is that BRCA1 is a dominant predisposing gene which is very near a still unknown tumour suppressor gene and that the observed loss is not directed at BRCA1.

Although $60 \%$ of sporadic ovarian tumours and $40 \%$ of breast tumours have allele losses on chromosome $17,{ }^{3334}$ narrowing of the BRCA1 region has not been possible as detailed mapping studies have not given clear results. A number of studies have shown that there are at least three regions of $\mathrm{LOH}$ on chromosome 17q. ${ }^{33-36}$ Furthermore, we are left with the unresolved question of why the best defined region of $\mathrm{LOH}^{37}$ (close to BRCA1) does not appear to coincide with the BRCAl region suggested by linkage. Interestingly, when $\mathrm{LOH}$ of chromosome 17 is observed in ovarian tumours it very frequently involves the entire q-arm or the whole chromosome. ${ }^{3839}$

\section{Practical applications}

PRESENT GENETIC DIAGNOSIS

Although BRCA1 has not yet been cloned it is now possible, within a few families which are unequivocally linked to BRCA1, to identify those women who may carry the mutation before onset of cancer. This type of linkage based analysis is presently limited to research laboratories with access to extended families in which analysis of many individuals with chromosome 17 markers linked to BRCA1 provides sufficient information to identify gene carriers with a high degree of certainty. The risk of breast and ovarian cancer in carriers of the BRCA1 mutation has been estimated and applied in counselling women from high risk breast-ovarian cancer families. ${ }^{40-42}$ Such pre- symptomatic testing will make it possible to focus on high risk individuals who can then be rigorously followed. At the same time, family members with a low risk can be identified, in whom the frequency of examination can be lowered. ${ }^{43}$ Currently, choices available to women with a high risk of having inherited the gene are surveillance (that is, breast selfexamination, annual examination by a specialist, mammography, vaginal ultrasound, and CA125 tumour marker determination) and surgery (prophylactic oophorectomy or mastectomy). ${ }^{4244}$ This approach has important ethical and psychosocial implications which must be carefully considered..$^{4045}$

FUTURE APPLICATION OF GENETIC TESTING IN DIAGNOSIS, PROGNOSIS AND TREATMENT

Cloning BRCA1 will permit more precise identification of women at high risk as the sequence of the gene will then be known and direct determination of mutation(s) will be possible. There will also be a much wider application in small families.

At this stage it is unclear why certain women in BRCA1 linked families develop breast cancer and other women in the same family develop ovarian cancer. Once the gene is cloned and the variant sequences are known, it will be possible to determine whether some mutant alleles predispose to breast cancer only and others predispose to both breast and ovarian cancer.

Important for clinical management of patients will be the association of genetic alterations with prognosis. The correlation between region or type of mutation and severity of disease have been illustrated in other cancers and have practical implications with regard not only to prognosis but also to treatment. In the future, knowledge of the gene sequence and the mutations may make it possible to devise treatment directed against, or to replace, the altered gene product(s).

\section{Other genes}

In addition to those families in which breast cancer development is the dominant feature, there are two syndromes where increased risk for breast cancer is also found: $\mathrm{Li}$-Fraumeni syndrome and ataxia telangiectasia.

\section{LI-FRAUMENI SYNDROME}

Germline mutations in the p53 tumour suppressor gene on the short arm of chromosome 17 have been implicated in the development of a wide range of malignancies, ${ }^{46}$ including a small proportion of breast cancers. ${ }^{47}$ Germline mutations within the p53 gene account for at least $50 \%$ of the families who suffer from $\mathrm{Li}$-Fraumeni syndrome, ${ }^{48}$ a familial predisposition to early-onset breast cancer, soft tissue sarcomas, brain tumours, osteosarcomas, and other neoplasms. ${ }^{9}$ Transmission of the $\mathrm{Li}-$ Fraumeni syndrome is autosomal dominant and members of these families usually have one mutant p53 allele and one wild-type p53 allele. Those individuals who develop cancer retain 
the mutant allele and lose the wild-type p53 allele in their tumour tissues, indicating that the inactivation of $\mathrm{p} 53$ is important in the development of cancer.

The p53 protein is a transcription factor which appears to be involved with the progression of the cell through the G1/S phase checkpoint in the cell cycle. ${ }^{49}$ Normal p53 acts as a monitor of genomic stability-if DNA is damaged p53 switches off replication to allow for repair. Although Jolly et $a l^{50}$ recently reported a splice-site mutation in seven members of a breast-ovarian cancer family, four of whom have developed breast, ovarian or choroid plexus tumours before age 35 years, no clear associations between germline p53 mutations and inheritance of breast cancer, in families with a strong history of breast cancer, have been made. ${ }^{5152}$ This suggests that familial breast cancer is not usually due to inheritance of $\mathrm{p} 53$ mutations.

\section{ATAXIA TELANGIECTASIA}

Ataxia telangiectasia is an autosomal recessive disease characterised by progressive cerebellar ataxia and oculocutaneous telangiectasia. Affected patients have an increased risk of developing cancer and asymptomatic heterozygous family members are also at increased risk of developing several types of cancer, especially breast cancer. ${ }^{1053}$ There are four ataxia telangiectasia complementation groups (A, C, $\mathrm{D}$, and $\mathrm{E}$ ) with groups $\mathrm{A}$ and $\mathrm{C}$ comprising $83 \%$ of cases. The gene for ataxia telangiectasia complementation group $A$ has been mapped to chromosome $11 \mathrm{q} 23,{ }^{54}$ but has not been cloned. Various studies have failed to detect linkage between the ataxia telangiectasia gene and familial breast cancer. ${ }^{556}$ It is probable, however, that mutations in the ataxia telangiectasia gene(s) contribute to breast cancer in the general population but do not give rise to multiple cases in one family, thus making it difficult to detect using linkage analysis.

\section{MALE BREAST CANCER}

Little is known about the genes responsible for predisposition to male breast cancer. Two studies have shown the androgen receptor gene to be involved in two families with male breast cancer. Wooster et $a l^{57}$ reported a family in which two brothers with breast cancer both had germline mutations in the DNA binding domain of the androgen receptor gene. This association was subsequently confirmed in one other family. ${ }^{58}$

\section{Concluding remarks}

At the present time four genes are known to be responsible for inherited susceptibility to breast cancer: BRCA1, p53, ataxia telangiectasia gene(s), and the androgen receptor gene. Evidence from linkage and population studies suggests that these genes may account for approximately half of the observed familial clustering of breast cancer. ${ }^{8}$ Other genes which confer a predisposition to breast cancer have yet to be identified.
With the present knowledge of BRCA1, and using linkage analysis, it is possible to identify individuals at high risk of carrying a BRCA1 mutation in a few extensive families, and for these individuals, genetic counselling can be given. In the future when the predisposing genes have been cloned new opportunities for diagnosis and treatment will become possible.

\section{Note added in proof}

BRCA1 has recently been cloned by Miki et al. ${ }^{59}$ It is a large gene composed of 22 exons (containing 5592 nucleotides) spread over approximately 100000 bases of genomic DNA adjacent to the locus D17S855. The protein sequence (1863 amino acids) contains a zinc finger domain in its amino-terminal region, but is otherwise unrelated to previously described proteins. This zinc finger motif is often found in proteins which act as transcription factors (which regulate the transcription of DNA into mRNA). This suggests that BRCA1 may have a role in DNA transcription. The initial evidence that this gene was BRCAl hinged on the discovery of mutations in the gene in five families who had previously shown strong linkage to $17 q$ markers. This was later verified by several groups. ${ }^{60-62}$ Mutations have been found in many different regions of the gene, $70 \%$ of which result in the loss or premature termination of the BRCA1 protein. This seems to be consistent with the idea that BRCA1 is a tumour suppressor gene. Because the mutations are scattered throughout the gene, screening women on a large scale (if it becomes appropriate in the future) will be technically difficult. Added to this is the surprising finding by Futreal et $a l^{63}$ that no somatic BRCA1 mutations occur in sporadic breast and ovarian cancers. This implies that BRCA1 mutations may be relatively unimportant in sporadic cancers. At present, prospects for large scale screening of BRCA1 mutations look dim.

At the same time that BRCA1 was cloned another genomic linkage search located a new breast cancer susceptibility gene, BRCA2, on chromosome 13q12-13. ${ }^{64}$ Allele losses in sporadic tumours suggest that BRCA2 may also be a tumour suppressor gene. If candidate genes on chromosome 13 are excluded, further positional cloning research will have to be carried out to clone BRCA2.

1 Newman B, Austin MA, Lee M, King M-C. Inheritance of human breast cancer: evidence for autosomal dominant transmission in high-risk families. Proc Natl Acad Sci USA 1988;85:3044-8.

2 Schildkraut JM, Thompson WD. Familial ovarian cancer: a population based case-control study. Am $\mathcal{f}$ Epidemiol 1988;128:456-66.

3 Schildkraut JM, Risch N, Thompson WD. Evaluating genetic association among ovarian, breast, and endometrial cancer: evidence for a breast/ovarian cancer relationship. Am f Hum Genet 1989;45:521-9.

4 Claus EB, Risch NJ, Thompson WD. Age of onset as an indicator of familial risk of breast cancer. Am $\mathcal{\exists}$ Epidemiol 1990;131:961-72.

5 Claus EB, Risch N, Thompson WD. Genetic analysis of breast cancer in the cancer and steroid hormone study. Am f Hum Genet 1991;48:232-41.

6 Williams WR, Anderson DE. Genetic epidemiology of breast cancer: segregation analysis of $200 \mathrm{Danish}$ pedigrees. Genet Epidemiol 1984;1:7-20.

7 Iselius L, Slack J, Litter M, Morton NE. Genetic epidemiology of breast cancer in Britain. Ann Hum Genet 1991;55:151-9.

8 Easton D, Ford D, Peto J. Inherited susceptibility to breast cancer. Cancer Surv 1993;18:95-113. 
9 Li FP, Fraumeni JF, Mulvihill J, Blattner WA, Dreyfus MG, Tucker MA, et al. A cancer family syndrome in twenty-four kindreds. Cancer Res 1988;48:5358-62.

10 Swift M, Reitnauer PJ, Morrell D, Chase CL. Breast and other cancers in families with ataxia telangiectasia. $N$ Engl f Med 1987;316:1289-94.

11 Ott J. Analysis of human genetic linkage. Revised edn. Baltimore: Johns Hopkins University Press, 1991.

12 Weber JL, May PE. Abundant class of human DNA polymorphisms which can be typed using the polymerase chain reaction. Am 7 Hum Genet 1989;44:388-96.

13 Weber JL. Informativeness of human (dC-dA)n(dG-dT)n polymorphisms. Genomics 1990;7:524-30.

14 Hall JM, Lee MK, Newman B, Morrow JE, Anderson LA, Huey $\mathrm{B}$, et al. Linkage of early-onset familial breast cance to chromosome 17q12-21. Science 1990;250:1684-9.

15 Margaritte $P$, Bonaiti-Pellie C, King M-C, Clerget-Darpoux F. Linkage of familial breast cancer to chromosome $17 \mathrm{q} 21$ may not be restricted to early-onset disease. Am $\mathcal{F}$ Hum Genet 1992;50:1231-4.

16 Narod SA, Feunteun J, Lynch HT, Watson P, Conway T, Lynch J, et al. Familial breast-ovarian cancer locus on Lynch J, et al. Familial breast-ovarian cancer

17 Solomon E, Ledbetter DH. Report of the Committee on the Genetic Constitution of chromosome 17. Cytogene Cell Genet 1991;58:686-738.

18 Easton DF, Bishop DT, Ford D, Crockford GP and the Breast Cancer Linkage Consortium. Genetic linkage analysis in familial breast and ovarian cancer: results from 214 families. Am f Hum Genet 1993;52:678-701.

19 Stratton MR, Ford D, Neuhasen S, Seal S, Wooster R, Friedman LS, et al. Familial male breast cancer is not linked to the BRCA1 locus on chromosome 17q. Nature Genet 1994;7:103-7.

20 Goldgar DE, Fields P, Lewis CM, Tran TD, CannonAlbright LA, Ward $\mathrm{JH}$, et al. A large kindred with $17 \mathrm{q}$ linked breast and ovarian cancer: genetic, phenotypic, and genealogical analysis. F Natl Cancer Inst 1994;86:200-9.

21 Smith SA, Dicioccio RA, Struewing JP, Easton DF, Gallion $\mathrm{HH}$, Albertsen $\mathrm{H}$, et al. Localisation of the breast-ovarian cancer susceptibility gene (BRCA1) on 17q12-21 to an interval of $<1 \mathrm{cM}$. Genes Chromosom Cancer 1994;10:71-6.

22 Bowcock AM, Anderson LA, Friedman LS, Black DM, Osborne-Lawrence SM, Rowell SE, et al. THRA1 and cancer gene (BRCA1) on chromosome 17q21. Am $\mathcal{F}$ Hum Genet 1993;52:718-22.

23 Simard J, Feunteun J, Lenoir G, Tonin P, Normand T, Teh $\mathrm{VL}$, et al. Genetic mapping of the breast-ovarian cancer syndrome to a small interval on chromosome 17q12-21: syndrome to a small interval on chromosome 17q12-21:
exclusion of candidate genes EDH17B2 and RARA. Hum exclusion of candidate genes

24 Kelsell DP, Black DM, Bishop DT, Spurr NK. Genetic analysis of the BRCAl region in a large breast/ovarian family: refinement of the minimal region containing BRCA1. Hum Molec Genet 1993;2:1823-8.

25 Bishop JM. Molecular themes in oncogenesis. Cell 1991;64: 235-48.

26 Levine AJ. The tumour suppressor genes. Annu Rev Biochem 1993;62:623-51.

27 Knudson AG. Mutation and cancer; statistical study of retinoblastoma. Proc Natl Acad Sci USA 1971;68:820-3.

28 Lasko D, Cavenee W, Nordenskjold M. Loss of constitutional heterozygosity in human cancer. Annu Rev Genet 1991;25:281-314

29 Ponder BAJ. Molecular genetics of cancer. BMF 1992;304: 1234-6.

30 Kamb A, Gruis NA, Weaver-Feldhaus J, Liu Q, Harshman $\mathrm{K}$, Tavtigian SV, et al. A cell cycle regulator potentially involved in genesis of many tumor types. Science 1994; 264:436-44.

31 Nobori T, Miura K, Wu DJ, Lois A, Takabayashi K, Carson D. Deletions of the cyclin-dependent kinase-4 inhibitor gene in multiple human cancers. Nature 1994;368:753-6.

32 Smith SA, Easton DF, Evans DGR, Ponder BAJ. Allele loss in the region $17 \mathrm{q} 12-21$ in familial breast and ovarian cancer involves the wild-type chromosome. Nature Genet 1992;2:128-31.

33 Jacobs IJ, Smith SA, Wiseman RW, Futreal PA, Harrington $\mathrm{T}$, Osborne RJ, et al. A deletion unit on chromosome 17q in epithelial ovarian tumors distal to the familial breas ovarian cancer locus. Cancer Res 1993;53:1218-21.

34 Cornelis RS, Devilee P, van Vliet M, Kuipers-Dijkshoorn N, Kersenmaeker A, Bardoel A, et al. Allele loss patterns on chromosome $17 \mathrm{q}$ in 109 breast carcinomas indicate at least two distinct target regions. Oncogene 1993;8:781-5.

35 Nagai MA, Yamamoto L, Salaorni S, Pacheco MM, Brentani MM, Barbosa EM, et al. Detailed deletion mapping of chromosome segment $17 \mathrm{q} 12-21$ in sporadic breast tu-
mours. Genes Chromosom Cancer 1994;11:58-62.

36 Kirchweger R, Zellinger R, Schneeberger C, Speiser P, Louason G, Theillet C. Patterns of allele losses suggest the existence of five distinct regions of $\mathrm{LOH}$ on chro-

37 Cropp CS, Nevanlinna HA, Pyrhönen S, Stenman U-H, Salmikangas $\mathrm{P}$, Albertsen $\mathrm{H}$, et al. Evidence for involvement of BRCAl in sporadic breast carcinomas. Cancer Res 1994;54:2548-51.
38 Foulkes WD, Black DM, Stamp WH, Solomon E, Trowsdale J. Very frequent loss of heterozygosity throughout chromosome 17 in sporadic ovarian carcinoma. Int 7 Cancer 1993;54:220-5.

39 Tavassoli M, Ruhrberg C, Beaumont V, Reynolds K, Kirkham N, Collins WP, et al. Whole chromosome 17 loss in ovarian cancer. Genes Chrom Cancer 1993;8:195-8.

40 Biesecker BB, Boehnke M, Calzone K, Markel DS, Garber JE, Collins FS, et al. Genetic counselling for families with inherited susceptibility to breast and ovarian cancer. 7AMA 1993;269:1970-4.

41 Ford D, Easton DF, Bishop DJ, Narod SA, Goldgar DE. Risks of cancer in BRCA1-mutation carriers. Lancet 1994 343:692-5.

42 King M-C, Rowell S, Love SM. Inherited breast and ovarian cancer. What are the risks? What are the choices? $f A M A$ 1993;269:1975-80.

43 Porter DE, Steel CM, Cohen BB, Wallace MR, Carothers $A$, Chetty $\mathrm{U}$, et al. Genetic linkage analysis applied to unaffected women from families with breast cancer can discriminate high- from low-risk individuals. Br f Surg 1993;80:1381-5.

44 Evans DGR, Fentiman IS, McPherson K, Ashbury D, Ponder BAJ, Howell A. Familial breast cancer. BMF 1994; 308:183-7.

45 Vasen HFA. Screening in breast cancer families: Is it useful? Ann Med 1994;26:185-90.

46 Hollstein MC, Sidransky D, Vogelstein B, Harris CC. p53 mutations in human cancers. Science 1991;253:49-53.

47 Prosser J, Thompson AM, Cranston G, Evans HJ. Evidence that $\mathrm{p} 53$ behaves as a tumour suppressor gene in sporadic breast tumours. Oncogene 1990;5:1573-9.

48 Birch JM, Hartley AL, Tricker KJ, Prosser J, Condie A Kelsey AM, et al. Prevalence and diversity of constitutional mutations in the $\mathrm{p} 53$ gene among $21 \mathrm{Li}$-Fraumeni families. Cancer Res 1994;54:1298-1304.

49 Levine AJ, Perry ME, Chang A, Silver A, Dittmer D, Wu $\mathrm{M}$, et al. The 1993 Walter Hubert Lecture: The role of the p53 tumour-suppressor gene in tumorigenesis. $\mathrm{Br} \mathcal{F}$ Cancer 1994;69:409-16.

50 Jolly KW, Malkin D, Douglass EC, Brown TF. Splice-site mutation of the p53 gene in a family with hereditary breast-ovarian cancer. Oncogene 1994;9:97-102.

51 Prosser J, Elder PA, Condie A, MacFadyen I, Steel CM, Evans HJ. Mutations in p53 do not account for heritable breast cancer: a study in five affected families. $\mathrm{Br} \mathcal{F}$ Cancer 1991;63:181-4.

52 Warren W, Eeles RA, Ponder BAJ, Easton DF, Averill D, Ponder MA, et al. No evidence for germline mutations in exons 5-9 of the p53 gene in 25 breast cancer families. Oncogene 1992;7:1043-6.

53 Swift M, Morrell D, Massey RB, Chase CL. Incidence of cancer in 161 families affected with ataxia telangiectasia. $N$ Engl f Med 1991;325:1831-6.

54 Foroud T, Wei S, Ziv Y, Sobel E, Lange E, Chao A, et al. Localization of an ataxia-telangiectasia locus to a 3-cM interval on chromosome 11q23: linkage analysis of 111 families by an international consortium. Am 7 Hum Genet 1991;49:1263-79.

55 Cortessis V, Ingles S, Millikan R, Diep A, Gatti RA, Richardson L, et al. Linkage analysis of DRD2, a marker Richardson $\mathrm{L}$, et al. Linkage analysis of $\mathrm{DR}$ f, a marker premenopausal bilateral breast cancer. Cancer Res 1993; 53:5083-6.

56 Wooster R, Ford D, Mangion J, Ponder BA, Peto J, Easton $\mathrm{DF}$, et al. Absence of linkage to the ataxia-telangiectasia locus in familial breast cancer. Hum Genet 1993;92:91-4

57 Wooster R, Mangion J, Eeles R, Smith SA, Dowsett M, Averill $\mathrm{D}$, et al. A germline mutation in the androgen receptor gene in two brothers with breast cancer and Reifenstein syndrome. Nature Genet 1992;2:132-4.

58 Lobaccaro J-M, Lumbroso S, Belon C, Galtier-Dereure F, Bringer J, Lesimple T, et al. Male breast cancer and the androgen receptor gene. Nature Genet 1993;5:109-10.

59 Miki Y, Swensen J, Shattuck-Eidens D, Futreal PA, Harshman $\mathrm{K}$, Tavtigian $\mathrm{S}$, et al. A strong candidate for the breast and ovarian cancer susceptibility gene BRCA1. Science 1994;266:66-71.

60 Castilla LH, Couch FJ, Erdos MR, Hoskins KF, Calzone $\mathrm{K}$, Garber JE, et al. Mutations in the BRCAl gene in families with early-onset breast and ovarian cancer. Nature Genet 1994;8:387-91.

61 Simard J, Tonin P, Durocher F, Morgan K, Rommens J, Gingras S, et al. Common origins of BRCA1 mutations in Canadian breast and ovarian cancer families. Nature Genet 1994;8:392-98.

62 Friedman LS, Ostermeyer EA, Szabo CI, Dowd P, Lynch ED, Rowell SE, et al. Confirmation of BRCA1 by analysis of germline mutations linked to breast and ovarian cancer in ten families. Nature Genet 1994;8:399-404.

63 Futreal PA, Liu Q, Shattuck-Eidens D, Cochran C, Harshman K, Tavtigian S, et al. BRCAl mutations in primary breast and ovarian carcinomas. Science 1994;266: 120-2.

64 Wooster R, Neuhausen SL, Mangion J, Quirk Y, Ford D, Collins $\mathrm{N}$, et al. Localization of a breast cancer susceptibility gene, BRCA2, to chromosome 13q12-13. Science 1994;265:2088-90. 